\title{
Protein Kinase C-Binding Protein 1
}

National Cancer Institute

\section{Source}

National Cancer Institute. Protein Kinase C-Binding Protein 1. NCI Thesaurus. Code C105610.

Protein kinase C-binding protein 1 (1186 aa, $132 \mathrm{kDa}$ ) is encoded by the human ZMYND8 gene. This protein plays a role in protein kinase $C$ function and may be a transcriptional regulator. 